\title{
PENGARUH RASIO KEUANGAN TERHADAP FINANCIAL DISTRESS PADA PERUSAHAAN SEKTOR PERDAGANGAN ECERAN DI BURSA EFEK INDONESIA TAHUN 2015-2018
}

\author{
Anita Damajanti ${ }^{1}$ \\ Hasnita Wulandari ${ }^{2}$ \\ Rosyati $^{3}$ \\ anitadamajanti@usm.ac.id ${ }^{1}$ \\ Fakultas Ekonomi Universitas Semarang
}

Diterima : November 2020, Disetujui : Desember 2020, Dipublikasikan: Januari 2021

\begin{abstract}
Business competition in the retail trade sector is currently very tight. In this condition, several outlets closed their businesses. The factors causing the closure of big retails in several places are the habits of consumers who switch shopping to online, decreased purchasing power, and internal factors within the company. This study aims to test empirically the effect of financial ratios on financial distress in retail trading companies listed on the Indonesia Stock Exchange in 2015-2018. The financial ratios analyzed are profitability, liquidity, leverage, activity, and sales growth. The Financial Distress variable is proxied using the Altman Z-Scored formula. The data were obtained from retail trade companies listed on the Indonesia Stock Exchange (IDX) in 2015-2018. Companies that meet the sample criteria are 19 companies. Based on the panel data method, 76 data were obtained from 19 companies for 4 years. The final results of the data that can be processed are 74 data. Hypothesis testing uses multiple linear regression The results of hypothesis testing show that partially the ratio of profitability, liquidity, leverage and sales growth has a significant effect on financial distress, while the ratio of activity has no significant effect on financial distress. Simultaneously, all variables have a significant effect on financial distress. The adjusted $R^{2}$ value of 0.955 shows that the ratio of profitability, liquidity, leverage, sales growth, and activity ratios is able to predict financial distress variables of $95.5 \%$ and the remaining $4.5 \%$ is predicted by variables outside the research model.
\end{abstract}

Keywords: Financial Distress, Financial Ratios, Retail Trade

\begin{abstract}
ABSTRAK
Persaingan usaha yang ketat di sektor perdagangan eceran atau retail mengakibatkan beberapa gerai menutup usahanya. Faktor penyebab tutupnya retail besar di beberapa tempat antara lain kebiasan masyarkat yang mengalihkan cara belanja ke online, daya beli masyarakat yang menurun dan lesu, dan faktor internal dari dalam perusahaan itu sendiri. Penelitian ini bertujuan untuk menguji secara empiris pengaruh rasio keuangan terhadap financial distress pada perusahaan sektor perdagangan eceran yang terdaftar di Bursa Efek Indonesia tahun 2015-2018. Rasio keuangan yang diteliti adalah rasio profitabilitas, likuiditas, leverage, aktivitas, dan sales growth. Variabel Financial Distress di proksikan menggunakan rumus Altman Z-Scored. Data diperoleh dari perusahaan sektor perdagangan eceran yang
\end{abstract}


terdaftar di Bursa Efek Indonesia (BEI) tahun 2015-2018. Sampel dipilih dengan metode purposive sampling. Perusahaan yang memenuhi kriteria sampel sebanyak 19 perusahaan. Berdasarkan metode data panel diperoleh 76 data dari 19 perusahaan selama 4 tahun. Tahap selanjutnya dilakukan uji outlier dan diperoleh hasil akhir data yang dapat diolah sebanyak 74 data. Pengujian hipotesis menggunakan regresi linear berganda untuk menguji pengaruh rasio keuangan secara parsial dan simultan terhadap financial distress. Hasil pengujian hipotesis menunjukkan bahwa secara parsial rasio profitabilitas, likuiditas, leverage dan sales growth berpengaruh signifikan terhadap financial distress, sedangkan rasio aktivitas tidak berpengaruh signifikan terhadap financial distress. Secara simultan semua variabel berpengaruh signifikan terhadap financial distress. Nilai adjusted $\mathrm{R}^{2}$ sebesar 0,955 menunjukkan bahwa rasio profitabilitas, likuiditas, leverage, sales growth, dan rasio aktivitas mampu memprediksi variabel financial distress sebesar 95,5\% dan sisanya yaitu 4,5\% diprediksi oleh variabel di luar model penelitian.

Kata Kunci : Financial Distress, Rasio Keuangan, Perdagangan Eceran

\section{PENDAHULUAN}

Perusahaan retail adalah perusahaan yang menjual berbagai barang kebutuhan konsumsi. Ketatnya persaingan yang terjadi membuat beberapa gerai retail yang menutup usahanya. Sejumlah perusahaan retail raksasa mengalami penurunan penjualan bahkan di ambang kebangkrutan. Antara lain ada Seven Eleven, Lotus, Debenhams, Hero, dan Central. Sepanjang tahun 2018 Hero Supermarket telah menutup 26 gerai jaringan ritel Giant Supermarket. Tak hanya Hero Supermarket saja yang tutup, PT Matahari Putra Prima Tbk (MPPA) juga menutup sebanyak enam gerai Hypermart di tahun 2018. (Saragih, 2019)

Banyak yang mendirikan usahanya lewat online karena dinilai pajak yang dibayarkan tidak besar, akibatnya banyak yang memulai bisnis dan menawarkan produknya lewat media online. Munculnya media belanja online ini mengubah tren belanja masyarakat, akibatnya membuat pertumbuhan perusahaan retail menurun. Menurut Wakil Ketua Umum Asosiasi Pengusaha Retail Indonesia (Aprindo) Tutum Rahanta, banyak faktor penyebab tutupnya retail besar di beberapa tempat seperti kebiasan masyarkat yang mengalihkan cara belanja ke online, lokasi yang tidak tepat, persaingan bisnis antar retail modern, daya beli masyarakat yang menurun dan lesu, faktor internal dari dalam perusahaan itu sendiri dan yang terakhir adalah pendapatan retail yang kecil. (Aprilianto, 2019)

Tabel 1.1 dan gambar 1.1 menunjukkan terdapat perusahaan yang mengalami penurunan laba dari tahun ke tahunnya, yang sangat mencolok adalah PT Matahari Putra Prima Tbk (MPPA) dan disusul dengan PT Hero Supermarket (HERO). Hal ini dibuktikan dengan banyaknya penutupan sejumlah gerai yang ada di Indonesia. Akibat penutupan gerai tersebut juga mengakibatkan karyawan terkena dampaknya yaitu banyak karyawan pekerja yang terkena Pemutusan Hubungan Kerja (PHK). Meskipun beberapa perusahaan juga mengalami penurunan laba selama beberapa tahun, namun di tahun 2018 perusahaan tersebut mampu bangkit dan dapat menghasilkan keuntungan. Fenomena laba perusahaan yang mengalami penurunan dari tahun ke tahun akan mengakibatkan kondisi financial distress. 
Tabel 1.1

Laba Bersih Perusahaan Sektor Perdagangan Eceran (dalam rupiah)

\begin{tabular}{|l|r|r|r|r|}
\hline \multirow{2}{*}{ KODE } & \multicolumn{4}{|c|}{ TAHUN } \\
\cline { 2 - 5 } & \multicolumn{1}{|c|}{$\mathbf{2 0 1 5}$} & \multicolumn{1}{|c|}{$\mathbf{2 0 1 6}$} & \multicolumn{1}{c|}{$\mathbf{2 0 1 7}$} & \multicolumn{1}{c|}{$\mathbf{2 0 1 8}$} \\
\hline CENT & $(63.392 .239 .973)$ & $(29.810 .785 .133)$ & $(119.047 .000 .000)$ & 35.637 .000 .000 \\
\hline ECII & 33.040 .963 .609 & $(32.270 .199 .731)$ & $(9.801 .947 .790)$ & 21.825 .792 .298 \\
\hline HERO & $(144.078 .000 .000)$ & 120.588 .000 .000 & $(191.406 .000 .000)$ & $(1.250 .189 .000 .000)$ \\
\hline GOLD & $(4.337 .631 .474)$ & $(1.298 .408 .463)$ & $(1.057 .304 .076)$ & $(8.081 .959 .089)$ \\
\hline KOIN & 14.408 .465 .567 & $(6.699 .824)$ & $(14.597 .991 .710)$ & $(9.993 .012 .908)$ \\
\hline MPPA & 221.741 .000 .000 & 38.483 .000 .000 & $(1.243 .414 .000 .000)$ & $(898.272 .000 .000)$ \\
\hline RIMO & $(4.726 .863 .219)$ & $(3.146 .812 .926)$ & 61.464 .405 .361 & 116.415 .688 .322 \\
\hline
\end{tabular}

Gambar 1.1

Grafik Perkembangan Laba (Rugi)

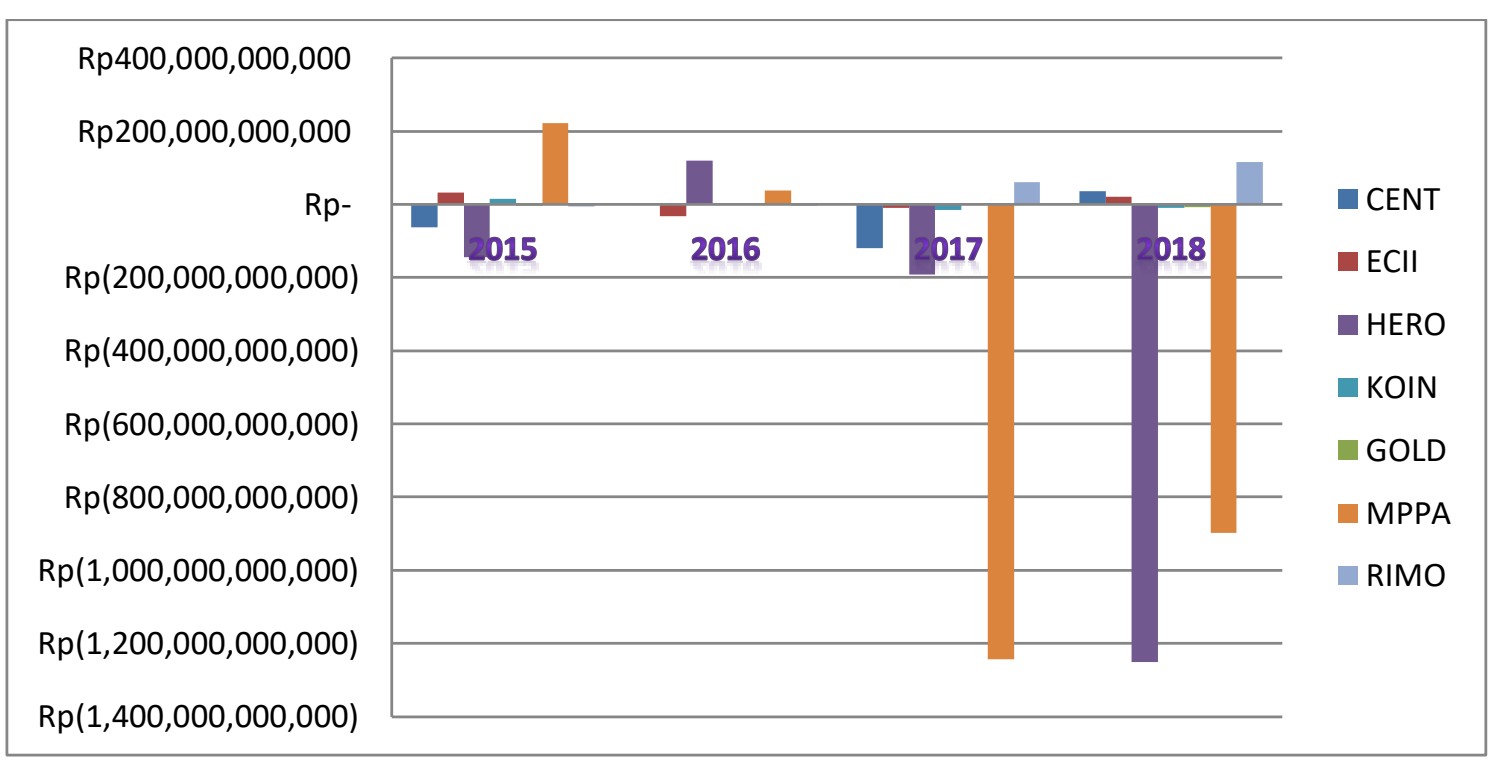

Platt dan Platt (2002) yang dikutip dalam Fahmiwati \& Luhgiatno (2017) menyatakan bahwa financial distress adalah tahap penurunan kondisi keuangan suatu perusahaan yang terjadi sebelum kebangkrutan ataupun likuidiasi terjadi. Kondisi financial distress ini juga digambarkan dengan ketidakmampuan perusahaan atau tidak tersedianya suatu dana untuk membayar kewajibannya yang telah jatuh tempo. Salah satu yang dapat dijadikan sebagai alat ukur untuk memprediksi terjadinya financial distress yaitu dengan melakukan pengukuran kinerja keuangan yang terdapat dalam laporan keuangan yang telah disusun secara akurat. Kinerja keuangan dapat diukur menggunakan rasio keuangan (Vionita \& Lusmeida, 2019).

Menururt Jauch dan Glueck yang dikutip dalam Surdayanti \& Dinar (2019) membagi 3 penyebab financial distress, yaitu faktor umum, faktor eksternal perusahaan dan faktor internal. Faktor umum penyebab financial distress adalah faktor yang terjadi secara umum pada suatu masyarakat, yang terdiri atas sektor usaha, sektor sosial, sektor teknologi dan sektor pemerintah. Faktor eksternal adalah faktor penyebab yang berasal dari spesifik pada 
suatu perusahaan yang berasal dari luar perusahaan, yang terdiri atas sektor pelanggan, sektor pemasok, dan sektor pesaing. Sedangkan faktor penyebab financial distress internal adalah faktor yang berasal dari internal perusahaan, berasal dari keputusan dan kebijakan yang tidak tepat yang diambil dari masa lalu, serta kegagalan manajemen membuat sesuatu yang diperlukan pada saat dibutuhkan.

Menurut Wongsosudono dan Chrissa dalam Vionita \& Lusmeida (2019) salah satu yang dapat dijadikan sebagai alat ukur untuk memprediksi terjadinya financial distress yaitu dengan melakukan pengukuran kinerja keuangan yang terdapat dalam laporan keuangan yang telah disusun secara akurat. Laporan keuangan merupakan informasi yang sangat dibutuhkan oleh pihak internal dan pihak eksternal perusahaan karena informasi tersebut dapat memberikan gambaran mengenai hasil yang telah dicapai oleh suatu perusahaan dalam jangka waktu tertentu, sehingga informasi tersebut dapat dijadikan sebagai bahan pertimbangan dalam pengambilan keputusan. Dengan adanya kinerja keuangan perusahaan yang baik maka kemungkinan terjadinya financial distress akan semakin kecil. Kinerja keuangan dapat diukur menggunakan rasio keuangan. Rasio keuangan merupakan angka yang diperoleh dari hasil perbandingan antara satu pos laporan keuangan dengan pos lainnya yang mempunyai hubungan yang relevan dan signifikan. Rasio keuangan dapat digunakan untuk mengevaluasi kondisi keuangan perusahaan dan kinerjanya.

Perusahaan harus mengenal gejala-gejala akan terjadinya kesulitan keuangan (financial distress) agar tidak terjadi kebangkrutan di perusahaan. Cara untuk mengetahuinya yaitu dengan melihat laporan keuangan perusahaan yang sudah diterbitkan di situs resmi Bursa Efek Indonesia (BEI). Setelah melihat laporan keuangan, maka dilakukan analisis rasio keuangan untuk mengetahui kondisi keuangan perusahaan yang sebenarnya secara lebih tepat dan detail agar tahu keadaan keuangan di perusahaan dan bisa memprediksi kondisi financial distress.

Rahayu \& Sopian (2017) melakukan penelitian Perusahaan Food and Beverage di Bursa Efek Indonesia periode 2013-2015. Variabel independen yang digunakan adalah likuiditas, leverage, sales growth, dan ukuran perusahaan. Hasil penelitian menunjukkan bahwa likuiditas, leverage, dan ukuran perusahaan tidak berpengaruh signifikan terhadap financial distress. Sedangkan sales growth berpengaruh terhadap financial distress.

Muhtar \& Aswan (2017) melakukan penelitian pada perusahaan telekomunikasi Indonesia yang tercatat di Bursa Efek Indonesia Periode 2008-2015. Variabel independen yang digunakan adalah profitabilitas, likuiditas, dan leverage. Hasil penelitian yang didapat yaitu profitabilitas, likuiditas, dan leverage sama-sama berpengaruh positif terhadap kemungkinan terjadinya financial distress.

Fahmiwati \& Luhgiatno (2017) melakukan penelitian dengan pada perusahaan sektor perdagangan eceran di Bursa Efek Indonesia periode 2012-2015. Variabel independen dipenelitian ini adalah Financial leverage, likuiditas, sales growth, dan aktivitas. Hasil penelitian menunjukkan bahwa financial distress dipengaruhi oleh financial leverage dan aktivitas. Variabel likuiditas dan sales growth tidak memiliki pengaruh terhadap financial distress perusahaan. 
Rani (2017) melakukan penelitian pada perusahaan manufaktur yang terdaftar di Bursa Efek Indonesia tahun 2012-2015. Penelitian ini menggunakan variabel bebas yaitu rasio likuiditas, leverage, agency cost dan sales growth. Hasil penelitian ini menunjukkan bahwa rasio leverage berpengaruh terhadap financial distress. Sedangkan rasio likuiditas, agency cost dan sales growth tidak berpengaruh terhadap kondisi financial distress .

Carolina, Pratama, \& Marpaung (2017) melakukan penelitian pada perusahaan manufaktur yang terdaftar di Bursa Efek Indonesia Periode 2014-2015. Variabel independen yang digunakan adalah profitabilitas, likuiditas, leverage, dan arus kas operasi. Hasil dari penelitian adalah profitabilitas berpengaruh dan dapat digunakan untuk memprediksi financial distress. Sedangkan likuiditas, leverage dan arus kas operasi tidak berpengaruh dan tidak dapat digunakan untuk memprediksi financial distress.

Zulaecha \& Mulvitasari (2018) melakukan penelitian pada perusahaan Properti, Real Estate, dan Konstruksi Bangunan yang tedaftar di Bursa Efek Indonesia periode 2015-2017. Variabel independen yang digunakan adalah likuiditas, leverage, dan sales growth. Hasil dari penelitian yaitu likuiditas memiliki pengaruh positif dan leverageberpengaruh negatif terhadap financial distress. Sedangkan sales growth tidak berpengaruh terhadap financial distress.

Surdayanti \& Dinar (2019) meneliti perusahaan batu bara yang terdaftar di Bursa Efek Indonesia periode 2014-2017. Variabel bebas dalam penelitan yaitu likuditas, financial leverage, profitabilitas, dan arus kas. Hasil dari penelitian menunjukkan likuiditas, financial leverage, dan arus kas tidak memiliki pengaruh yang signifikan terhadap financial distress. Sedangkan profitabilitas memberikan pengaruh signifikan terhadap kondisi financial distress.

Shidiq \& Khairunnisa (2019) meneliti perusahaan sub sektor tekstil dan garmen di Bursa Efek Indonesia periode 2013-2017. Variabel independen yang digunakan yaitu likuiditas, leverage, aktivitas, dan pertumbuhan. Secara simultan rasio likuiditas, leverage, aktivitas, dan pertumbuhan penjualan memiliki pengaruh terhadap financial distress. Secara parsial rasio likuiditas memiliki pengaruh terhadap financial distress. Sedangkan rasio leverage, aktivitas, dan pertumbuhan penjualan tidak memiliki pengaruh signifikan terhadap financial distess.

Yusbardini \& Rashid (2019) melakukan penelitian pada perusahaan manufaktur yang terdaftar di Bursa Efek Indonesia Periode 2013-2017. Variabel independen dalam penelitian yang digunakan adalah leverage, profitabilitas, likuditas, dan Firm Size. Hasil dari penelitian menunjukkan bahwa terdapat pengaruh yang signifikan antara leverage, profitabilitas, likuditas, dan firm size secara bersama-sama maupun parsial terhadap financial distress.

Vionita \& Lusmeida (2019) melakukan penelitian pada perusahaan manufaktur yang terdaftar di Bursa Efek Indonesia periode 2014-2017. Variabel independen dalam penelitian yang digunakan adalah leverage, likuiditas, profitabilitas, pertumbuhan penjualan, kepemililikan manajerial, kepemilikan institusional, dewan direksi, dewan komisaris independen, dan komite audit. Hasil dari penelitian menunjukkan secara parsial variabel leverage, dewan komisaris, dan dewan komisaris independen berpengaruh positif terhadap financial distress. Profitabilitas, kepemilikan manajerial berpengaruh secara negatif terhadap 
financial distress. Sedangkan likuiditas, pertumbuhan penjualan, kepemilikan institusional, dewan direksi, dan komite audit tidak berpengaruh terhadap financial distress.

\section{TELAAH PUSTAKA DAN PERUMUSAN HIPOTESIS}

Signalling theory atau teori sinyal yang dikembangkan oleh Ross (1977) menjelaskan mengenai dorongan atau alasan suatu perusahaan memberikan informasi tertentu kepada pihak luar. Teori tersebut dilatarbelakangi oleh asumsi bahwa pihak manajemen atau internal perusahaan memiliki informasi yang lebih lengkap mengenai kondisi perusahaan dibandingkan informasi yang dimiliki pihak luar. Berdasarkan kondisi tersebut, perusahaan akan berusaha menggunakan informasi yang mereka miliki untuk memberikan pesan kepada pihak luar mengenai kinerja yang mereka capai. (Surdayanti \& Dinar, 2019). Teori sinyal menekankan pentingnya informasi yang diterbitkan perusahaan terhadap keputusan investor sebagai pihak eksternal, investor selalu membutuhkan informasi yang lengkap, relevan, akurat, dan tepat waktu untuk menganalisis dalam mengambil keputusan. Teori sinyal merupakan sinyal-sinyal informasi yang dibutuhkan oleh investor untuk mempertimbangkan dan menentukan apakah para investor akan menanamkan sahamnya atau tidak pada perusahaan yang bersangkutan. (Zulaecha \& Mulvitasari, 2018).

Kondisi financial distress merupakan sinyal bagi investor untuk pengambilan keputusan. Menurut Altman (2005) dalam Rahayu \& Sopian (2017) financial distress adalah suatu konsep luas yang terdiri dari beberapa situasi dimana suatu perusahaan menghadapi masalah kesulitan keuangan, istilah umum untuk menggambarkan situasi tersebut aalah kegagalan, kepailitan, default, dan kebangkrutan. Apabila perusahaan gagal mencari jalan keluarnya, itu sudah menjadi pertanda bahwa perusahaan dalam kondisi financial distress diambang kebangkrutan.. Jika perusahaan memperlihatkan kondisi keuangan yang melemah, maka dapat membuat para pemegang kepentingan seperti kreditur dan pemegang saham kehilangan kepercayaannya. Dampak kondisi financial distress yaitu para stakeholder tersebut akan mundur untuk bekerjasama dengan perusahaan.

Berdasarkan penelitian sebelumnya terdapat beberapa variabel rasio keuangan yang mempengaruhi konidisi financial distress perusahaan yaitu profitabilitas, leverage, rasio aktivitas, dan pertumbuhan penjualan. Rasio profitabilitas perusahaan yang tinggi menunjukkan bahwa pengembalian investasi dari aset perusahaan sangat baik. Laba yang dihasilkan perusahaan cukup untuk mendanai operasional perusahaan dan mampu mengembalikan investasi dari investor. Hal ini juga menunjukkan bahwa kondisi keuangan perusahaan dalam keadaan baik dan jauh dari kondisi financial ditress. Semakin meningkatnya keuntungan yang dicapai perusahaan, maka akan menunjukkan kinerja keuangan perushaaan semakin baik sehingga dengan begitu perusahaan akan semakin jauh dari kondisi financial distress (Rani, 2017). Penelitian Muhtar \& Aswan (2017), Vionita \& Lusmeida (2019), (Carolina, Pratama, \& Marpaung, (2017), Surdayanti \& Dinar (2019), Yusbardini \& Rashid, (2019) menunjukkan bahwa profitabilitas berpengaruh terhadap financial distress.

H1 : Profitabilitas memiliki pengaruh terhadap financial distress. 
Rasio likuditas menunjukkan sejauh mana aktiva lancar menutupi kewajibankewajiban lancar. Semakin besar perbandingan aktiva lancar dengan hutang lancar maka semakin tinggi kemampuan perusahan menutupi kewajiban jangka pendeknya, jadi semakin likuid suatu perusahaan mengindikasikan perusahaan tersebut mampu membayar kewajiban yang akan jatuh tempo dan akan semakin kecil kemungkinan perusahaan mengalami financial distress (Rahayu \& Sopian, 2017). Likuiditas menunjukkan kemampuan perusahaan untuk membayar kewajiban finansial jangka pendek tepat pada waktunya. Perusahaan yang mengalami tingkat likuiditas yang tinggi mengindikasikan perusahaan memiliki sejumlah aset lancar yang siap untuk membayar utang jangka pendeknya. Dengan demikian perusahaan tersebut dapat terhindar dari kondisi financial distress. . (Carolina, Pratama, \& Marpaung, 2017)

Hasil penelitian Zulaecha \& Mulvitasari (2018) dan Yusbardini \& Rashid (2019) menunjukkan rasio likuiditas yang diproksikan dengan current ratio berpengaruh terhadap kondisi financial distress dimana semakin tinggi rasio ini, maka akan semakin memperkecil peluang perusahaan terindikasi kondisi financial distress. Sebaliknya apabila semakin kecil rasio likuiditas maka akan memperbesar peluang perusahaan untuk terindikasi kondisi financial distress.. Berbeda dengan hasil penelitian Fahmiwati \& Luhgiatno (2017) dan Vionita \& Lusmeida (2019) bahwa likuditas tidak bepengaruh terhadap financial distress.

$\mathrm{H} 2$ : Likuiditas berpengaruh signifikan terhadap financial distress.

Leverage mengukur seberapa besar perusahaan dibiayai dengan utang. Penggunaan utang yang telah tinggi akan membahayakan perusahaan karena perusahaan akan masuk dalam kategori extemeleverage (utang eksterm) yaitu perusahaan terjebak dalam tingkat utang yang tinggi dan sulit untuk melepaskan beban utang tersebut (Fahmi, 2017). Leverage diproksikan dengan Debt to equity ratio. Semakin besar hutang maka semakin tinggi kemungkinan perusahaan tidak mampu melunasi hutang-hutangnya ketika jatuh tempo, sehingga dapat menjadi indikasi bahwa nantinya perusahaan akan mengalami financial distress.

Leverage adalah rasio untuk mengukur seberapa besar perusahaan menggunakan utang sebagai modalnya untuk membiayai jalannya perusahaan.perusahaan yang memiliki leverage yang tinggi berarti perusahaan tersebut lebih banyak menggunakan utang untuk membiayai operasional perusahaan. Akibat dari penggunaan utang yang terlalu besar adalah kebangkrutan, karena utang akan menimbulkan bunga yang harus ditanggung perusahaan. Hal ini akan mengakibatkan perusahaan cenderung akan mengalami financial distress (Carolina, Pratama, \& Marpaung, 2017).

Rasio leverage merujuk pada aktiva tetap dan sumber dana yang digunakan oleh perusahaan, dengan konsekuensi berupa biaya tetap atau beban tetap yang harus dikeluarkan perusahaan akibat penggunaan tersebut. Indikator untuk mengukur rasio leverage adalah debt to equity ratio (DER). Semakin besar rasio leverage maka semakin besar pula kewajiban yang dimiliki perusahaan. Besarnya kewajiban tetap tersebut membawa pada besarnya kemungkinan perusahaan berada dalam kondisi financial distress. (Surdayanti \& Dinar, 2019) 
Hasil penelitian Rani (2017) dan Muhtar \& Aswan (2017) menunjukkan bahwa leverage berpengaruh terhadap financial distress. Berbeda dengan Shidiq \& Khairunnisa (2019) dan Surdayanti \& Dinar (2019) yang hasilnya menunjukkan bahwa rasio leverage tidak berpengaruh terhadap financial distress.

$\mathrm{H} 3$ : Leverage memiliki pengaruh terhadap financial distress

Rasio aktivitas adalah rasio yang menggambarkan sejauh mana suatu perusahaan mempergunakan sumber daya yang dimilikinya guna menunjuang aktivitas perusahaan, dimana penggunaan aktivitas ini dilakukan secara sangat maksimal dengan maksud memperoleh hasil yang maksimal (Fahmi, 2017). Harahap (2013) menjelaskan bahwa rasio aktivitas menggambarkan aktivitas yang dilakukan perusahaan dalam menjalankan operasionalnya baik dalam kegiatan penjualan, pembelian dan kegiatan lainnya. Semakin efektif dalam memanfaatkan dana semakin cepat perputaran dana tersebut, karena rasio aktivitas umumnya diukur dari perputaran masing-masing elemen aset. Rasio aktivitas yaitu rasio untuk menilai kemampuan perusahaan dalam melaksanakanan aktivitasnya sehari-hari atau kemampuan suatu perusahaan dalam penjualan, penagihan piutang maupun dalam pemanfaatan aktiva yang dimiliki. Rasio aktivitas juga dapat mengukur seberapa efektif perusahaan dalam memanfaatkan semua sumber daya yang ada di suatu perusahaan. Rasio aktivitas ini melibatkan antara perbandingan tingkat penjualan dan investasi pada berbagai jenis aktiva. Dalam rasio aktivitas akan lebih baik jika terdapat keseimbangan yang layak antara penjualan dan beragam unsur aktiva misalnya persediaan, aktiva tetap dan aktiva lainnya. Hal ini akan memiliki pengaruh terhadap financial distress dimana jika rasio aktivitas tinggi maka kemungkinan untuk mengalami financial distress akan semakin rendah. Rasio aktivitas yaitu rasio untuk menilai kemampuan perusahaan dalam melaksanakan aktivitasnya sehari-hari. Menurut Kasmir (2015)total aset turnover merupakan rasio yang digunakan untuk mengukur perputaran semua aktiva yang dimiliki perusahaan dan mengukur berapa jumlah penjualan yang diperoleh dari tiap rupiah aktiva. Pada rasio ini, penelitian Fahmiwati \& Luhgiatno (2017) berpengaruh terhadap financial distress. Berbeda dengan hasil penelitian yang dilakukan oleh Shidiq \& Khairunnisa (2019) yang menunjukkan bahwa rasio aktivitas tidak berpengaruh terhadap financial distress.

H4 : Aktivitas memiliki pengaruh terhadap financial distress.

Sales growth mencerminkan kemampuan perusahaan untuk meningkatkan penjualan dari waktu ke waktu. Semakin tinggi tingkat pertumbuhan penjualan suatu perusahaan maka perusahaan tersebut berhasil dalam menjalankan strateginya dalam hal pemasaran dan penjualan produk. Hal ini berarti semakin besar pula laba yang akan diperoleh perusahaam dari penjualan tersebut.

Pertumbuhan penjualan yang tinggi akan menyebabkan laba yang akan diterima oleh suatu perusahaan juga akan semakin tinggi. Pertumbuhan penjualan itu sendiri mencerminkan kemampuan perusahaan dalam meningkatkan penjualan produk yang dihasilkan, baik peningkatan frekuensi penjualannya ataupun peningkatan volume penjualannya. Perusahaan yang berhasil menjalankan stratginya dalam hal pemasaran dan penjualan produk, akan meningkatkan sales growth perusahaan. (Rahayu \& Sopian, 2017). Tujuan utama dari setiap perusahaan adalah untuk memperoleh laba dari hasil usahanya. Untuk memperoleh laba tersebut dibutuhkan pertumbuhan penjualan yang cukup. Pertumbuhan penjualan perusahaan merupakan komponen untuk menilai prosepek perusahaan pada masa yang akan datang. 
Adapun pengaruh sales growth terhadap financial distress ketika perusahaan memiliki pertumbuhan penjualan yang tinggi maka akan menghasilkan laba yang besar dan kemungkinan perusahaan tersebut untuk mengalami kondisi financial distress akan semakin kecil. Menurut Harahap (2013) rasio pertumbuhan menggambarkan presentase pertumbuhan pos-pos perusahaan dari tahun ke tahun. Rasio pertumbuhan penjualan (sales growth) merupakan cerminan dari kinerja manajemen suatu perusahaan untuk dapat meningkatkan penjualan dari satu periode ke periode selanjutnya. sales growth mencerminkan presentasi kenaikan penjualan tahun ini yang dibandingkan dengan tahu sebelumnya, semakin tinggi sales growth maka akan semakin baik karena perusahaan tersebut berhasil menjalankan startegi pemasaran dan penjualan produk. Jika semakin rendah sales growth maka akan semakin besar pula kemungkinan financial distress. (Zulaecha \& Mulvitasari, 2018)

Sales growth menggambarkan presentasi pertumbuhan pos-pos perusahaan dari tahun ke tahun. Rasio ini menunjukkan presentasi kenaikan penjualan tahun ini dibanding dengan tahun lalu. Semakin tinggi semakin baik (Harahap, 2013). Penelitian yang dilakukan oleh Rahayu \& Sopian (2017) menunjukkan adanya pengaruh sales growth terhadap financial distress. Sedangkan penelitian Vionita \& Lusmeida (2019) menunjukkan bahwa sales growth tidak berpengaruh terhadap financial distress.

H5 : Sales growth memiliki pengaruh terhadap financial distress.

\section{Gambar 2.1}

\section{Kerangka Pemikiran}

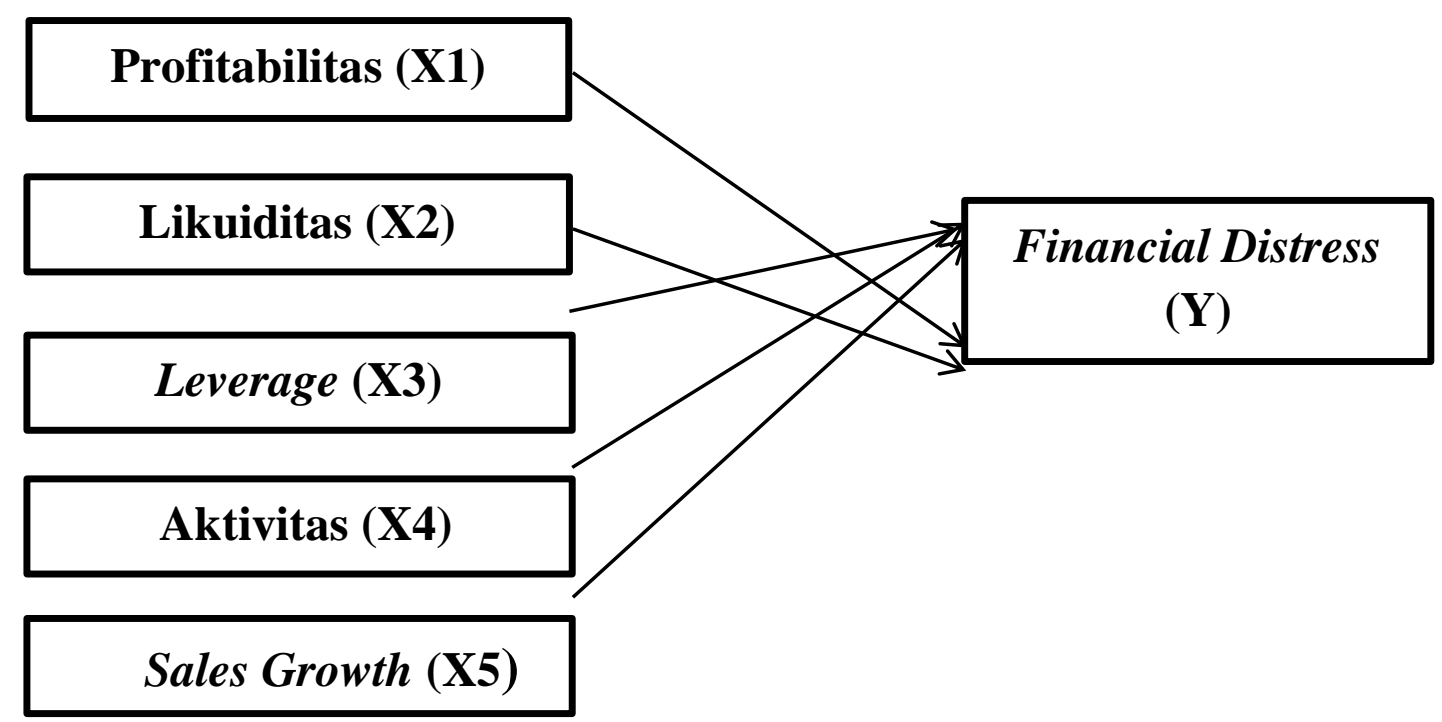

\section{METODE PENELITIAN}

Populasi yang digunakan dalam penelitian ini adalah perusahaan sektor perdagangan eceran yang terdaftar di Bursa Efek Indonesia (BEI) tahun 2015-2018. Sampel dipilih dengan metode purposive judgment sampling dengan kriteria yaitu menggunakan mata uang rupiah, terdaftar di Bursa Efek Indonesia selama 4 (empat)_ tahun berturut-turut yaitu tahun 20152018, dan tersedia data lengkap untuk semua variabel yang digunakan dalam penelitian ini. Unit sampel dalam penelitian ini adalah laporan tahunan (annual report) perusahaan sektor 
perdagangan eceran yang terdaftar di Bursa Efek Indonesia (BEI) tahun 2015-2018 yang diperoleh dari situs resmi Bursa Efek Indonesia yaitu www.idx.co.id.

Pengujian hipotesis dilakukan dengan alat analisis regresi linier berganda. Variabel yang digunakan yaitu financial distress sebagai variabel dependen sedangkan variabel independen yang digunakan yaitu profitabilitas, likuiditas, leverage, rasio aktivitas, dan pertumbuhan penjualan. Profitabilitas diukur menggunakan Return On Assets (ROA). Rumus yang digunakan adalah:

$$
\text { Return On Asset }=\frac{\text { Laba Bersih }}{\text { Total Aset }}
$$

Likuiditas diukur menggunakan current ratio dengan rumus sebagai berikut:

$$
\text { Current Ratio }=\frac{\text { Aktiva Lancar }}{\text { Utang Lancar }}
$$

Leverage diukur dengan Debt to Equity Ratio (DER) dengan rumus perhitungan sebagai berikut :

$$
\text { Debt to Equity Ratio }=\frac{\text { Total Utang }}{\text { Modal }}
$$

Rasio aktivitas diukur dengan rasio perputaran aset. Rumus yang digunakan adalah sebagai berikut :

$$
\text { Total Aset Turn Over }=\frac{\text { Penjualan }}{\text { Total Aset }}
$$

Pertumbuhan penjualan (sales growth) adalah rasio yang menggambarkan suatu perusahaan dalam mempertahankan posisi ekonominya ditengah pertumbuhan perekonomian dan sektor usahanya. Sales growth dirumuskan sebagai berikut:

$$
\text { Sales Growth }=\frac{\text { Penjualan } \mathrm{t}-\text { Penjualan Tahun } \mathrm{t}-1}{\text { Penjualan } \mathrm{t}-1}
$$

Variabel dependen dalam penelitian ini adalah financial distress. Pengukuran variable financial distress menggunakan model Altman Modifikasi. Persamaan model Altman Modifikasi yang digunakan pada perusahaan non manufaktur adalah sebagai berikut:

$$
Z "=6,56 X_{1}+3,26 X_{2}+6,72 X_{3}+1,05 X_{4}
$$

Dimana :

$\mathrm{X}_{1}=$ Modal Kerja/ Total Asset

$\mathrm{X}_{2}=$ Laba ditahan/ Total Aset

$\mathrm{X}_{3}=$ Laba sebelum bunga dan pajak/ Total Aset

$\mathrm{X}_{4}=$ Nilai Buku Ekuitas/ Modal

Klasifikasi perusahaan yang bangkrut berdasarkan pada nilai Z-Score model Altman Modifikasi sebagai berikut: 
1. Jika nilai Z" $<1,1$ maka termasuk perusahaan yang bangkrut.

2. Jika nilai $1,1<Z$ " $<2,6$ maka perusahaan termasuk dalam grey area (tidak dapat ditentukan apakah perusahaan sehat ataupun mengalami kebangkrutan).

3. Jika nilai Z" > 2,6 maka perusahaan termasuk dalam area tidak bangrut (sehat).

Berdasarkan variable-variabel yang telah dijelaskan tersebut disusun persamaan regresi sebagai berikut :

$\mathrm{FD}=\alpha_{0}+\beta_{1} \mathrm{ROA}+\beta_{2} \mathrm{CR}+\beta_{3} \mathrm{DER}+\beta_{4} \mathrm{TATO}+\beta_{5} \mathrm{SG}+\mathrm{e}$

FD = Financial Distress

ROA $=$ Return on Aset

$\mathrm{CR}=$ Current Ratio

DER = Debt to Equity Ratio

TATO = Total Aset Turn Over

$\mathrm{SG}=$ Sales Growth

\section{HASIL DAN PEMBAHASAN}

Data yang diperoleh dari situs resmi Bursa Efek Indonesia menunjukkan sebanyak 25 perusahaan sektor perdagangan dan eceran terdaftar di Bursa Efek Indonesia selama 4 (empat) tahun berturut-turut mulai tahun 2015-2018. Enam perusahaan dikeluarkan sebagai sampel karena tidak menggunakan mata uang rupiah dalam pelaporan keuangannya. Hasil seleksi sampel diperoleh 19 perusahaan yang terdaftar selama 4 (empat) tahun berturut-turut, sehingga jumlah data yang digunakan dalam penelitian ini yaitu sebesar $19 \times 4=76$ data.

Hasil uji normalitas residual pada 76 data dengan uji Kolmogorov-Smirnov menunjukkan nilai signifikansi 0,000 lebih kecil dari 0,05 yang berati residual tidak terdistribusi normal. Langkah selanjutnya dilakukan uji outlier untuk membuang data yang bersifat ekstrim yang menyebabkan residual tidak berdistribusi normal . Pengujian Kolmogorov-Smirnov dilakukan kembali setelah menghapus 2 (dua) data yaitu data nomor 17 dan 36. Hasilnya menunjukkan nilai siginifikansi untuk uji Kolmogorov-smirnov adalah sebesar 0,200 lebih besar dari 0,05.

Hasil pengujian multikolinieritas pada tabel 4.7 menunjukkan bahwa semua angka VIF yang dihasilkan memiliki nilai dibawah 10 dan tolerance value diatas 0,10 . Nilai VIF terbesar adalah 1,456 dan terkecil adalah 1,025 yang berati masih lebih kecil atau kurang dari 10. Sedangkan nilai terbesar 0,975 dan nilai terkecil tolerance value adalah 0,687 yang berati lebih besar dari 0,10. Dari angka-angka tersebut dapat disimpulkan tidak terdapat multikolinieritas, sehingga persamaan layak digunakan.

Pengujian heterokedastisitas dilakukan dengan menggunkan uji park yaitu dengan melakukan regresi variable independent dengan LnU2i. Hasil pengujian menunjukkan variabel profitabilitas (ROA) memiliki nilai signifikan 0,369, likuiditas (CR) memiliki nilai signifikan 0,281 , leverage (DER) memiliki nilai signifikan 0,114, aktivitas (TATO) memiliki nilai 
signifikan 0,053, dan Sales growth memiliki nilai signifikan sebesar 0,422. Semua variabel diatas menunjukkan bahwa nilai signifikansi diatas 0,05 maka dalam persamaan ini dapat disimpulkan bahwa model regersi tidak terdapat heteroskedastisitas.

Gejala autokorelasi dideteksi dengan menggunakan uji Durbin-Watson (DW). Hasil pengujian diperoleh nilai DW sebesar 1,959 nilai ini selanjutnya akan dibandingkan dengan nilai tabel DU yaitu 1,7694. Hasilnya menunjukkan DU < DW < 4 - DU, yaitu 1,7694 < 1,959 < 2,2306 dan dapat disimpulkan bahwa tidak terjadi autokorelasi.

Setelah regresi memenuhi kriteria uji asumsi klasik Langkah berikutnya adalah melakukan uji hipotesis untuk uji parsial dan uji simultan dengan menggunakan analisis regresi linier berganda. Hasil uji parsial dan uji simultan dapat dilihat pada table berikut ini.

Tabel 4.11

\section{Hasil Analisis Regeresi Linier Berganda}

\section{Coefficients $^{\mathrm{a}}$}

\begin{tabular}{|c|c|c|c|c|c|c|}
\hline \multirow{2}{*}{\multicolumn{2}{|c|}{ Model }} & \multicolumn{2}{|c|}{$\begin{array}{l}\text { Unstandardized } \\
\text { Coefficients }\end{array}$} & \multirow{2}{*}{$\begin{array}{c}\text { Standardized } \\
\text { Coefficients }\end{array}$} & \multirow[b]{2}{*}{$\mathrm{T}$} & \multirow[b]{2}{*}{ Sig. } \\
\hline & & B & Std. Error & & & \\
\hline \multirow[t]{6}{*}{1} & (Constant) & 1,358 &, 285 & & 4,763 &, 000 \\
\hline & ROA & 11,736 & 1,066 & 277 & 11,008 & ,000 \\
\hline & $\mathrm{CR}$ & 1,261 &, 044 & ,815 & 28,911 & ,000 \\
\hline & DER &,- 529 & ,091 &,- 174 & $-5,817$ & ,000 \\
\hline & TATO &,- 090 &, 101 &,- 024 &,- 887 & ,378 \\
\hline & SG &, 001 & ,000 & ,091 & 3,592 & ,001 \\
\hline
\end{tabular}

a. Dependent Variable: FINANCIAL DISTRESS

\section{Sumber : Output SPSS 23, data diolah 2019}

Berikut disajikan uji F statistik dalam penelitian ini :

Tabel 4.12

Hasil Uji F

ANOVA $^{\mathrm{a}}$

\begin{tabular}{|c|c|c|c|c|c|c|}
\hline \multicolumn{2}{|c|}{ Model } & $\begin{array}{l}\text { Sum of } \\
\text { Squares }\end{array}$ & Df & Mean Square & $\mathrm{F}$ & Sig. \\
\hline \multirow[t]{3}{*}{1} & Regression & 1377,041 & 5 & 275,408 & 311,295 &, $000^{\mathrm{b}}$ \\
\hline & Residual & 60,161 & 68 & ,885 & & \\
\hline & Total & 1437,201 & 73 & & & \\
\hline
\end{tabular}

a. Dependent Variable: FINANCIAL DISTRESS

b. Predictors: (Constant), SG, CR, ROA, TATO, DER

\section{Sumber : Output SPSS 23, data diolah 2019}

Berdasarkan uji regresi secara parsial menggunakan uji t pada table menunjukkan nilai signifikansi profitabilitas yaitu sebesar $0,000<0,05$. Sehingga dapat disimpulkan bahwa H1 
diterima yang berarti variabel profitabilitas berpengaruh terhadap financial distress. Nilai signifikansi likuiditas yaitu sebesar $0,000<0,05$. Sehingga dapat disimpulkan bahwa H2 diterima yang berarti variabel likuiditas berpengaruh terhadap financial distress. Nilai signifikansi leverage yaitu sebesar $0,000<0,05$. Sehingga dapat disimpulkan bahwa H3 diterima yang berarti variabel leverage berpengaruh terhadap financial distress. Nilai signifikansi aktivitas yaitu sebesar 0,378 > 0,05. Sehingga dapat disimpulkan bahwa H4 ditolak yang berarti variabel aktivitas tidak berpengaruh terhadap financial distress. Nilai signifikansi sales growth yaitu sebesar $0,001<0,05$. Sehingga dapat disimpulkan bahwa H5 diterima yang berarti variabel sales growth berpengaruh terhadap financial distress.

Hasil uji F diketahui bahwa nilai signifikansi sebesar 0,000 yang lebih kecil dari 0,05. Artinya bahwa variabel profitabilitas, likuditas, leverage, aktivitas, dan sales growth secara bersama-sama (simultan) berpengaruh terhadap financial distress. Koefisien Determinasi $\left(\mathrm{R}^{2}\right)$ pada intinya mengukur seberapa jauh kemampuan model variasi inedependen (profitabilias, likuditas, leverage, aktivitas, dan sales growth) dalam memprediksi variasi variabel dependen (financial distress). Berikut merupakan hasil koefisien determinasi ( $\left.\mathrm{R}^{2}\right)$ :

Tabel 4.13

Hasil Koefisien Determinasi

\begin{tabular}{|l|r|r|r|c|}
\hline Model & \multicolumn{1}{|c|}{$\mathrm{R}$} & R Square & $\begin{array}{c}\text { Adjusted R } \\
\text { Square }\end{array}$ & $\begin{array}{c}\text { Std. Error of the } \\
\text { Estimate }\end{array}$ \\
\hline 1 &, $979^{\mathrm{a}}$ &, 958 &, 955 &, 940594 \\
\hline
\end{tabular}

Berdasarkan hasil pengujian diperoleh nilai koefisien determinasi (Adjusted $R$ Square) sebesar 0,955. Hal ini berarti sebesar 95,5 persen variabel financial distress diprediksi oleh variabel profitabilitas, likuiditas, leverage, aktivitas, dan sales growth dan sisanya 4,5 persen dipengaruhi oleh variabel lain diluar model penelitian.

\section{PEMBAHASAN}

\section{Pengaruh Profitabilitas terhadap Financial Distress}

Hasil penelitian ini menunjukkan bahwa variabel Profitabilitas yang diukur menggunakan Return On Asset (ROA) berpengaruh positif terhadap financial distress., artinya jika nilai profitabilitas naik maka akan menaikkan nilai dari variabel financial distress, yang dimana artinya naiknya angka financial distress (z-score) menunjukkan bahwa perusahaan tersebut mengalami kondisi yang sehat atau menurunkan terjadinya kondisi financial distress. Perusahaan yang memiliki tingkat ROA yang tinggi mengindikasikan perusahaan tersebut mampu menghasilkan laba yang dapat digunakan untuk berbagai macam hal baik untuk mendanai aktivitas perusahaan maupun membayar kewajiban-kewajibannya. Dengan demikian perusahaan tersebut terhindar dari kondisi financial distress. Efektivitas penggunaan aset untuk menghasilkan laba baik dari penjualan maupun investasi akan membuat perusahaan betahan dan terhindar dari financial distress. Hasil penelitan ini mendukung penelitian yang dilakukan oleh (Muhtar \& Aswan , 2017) (Carolina, Pratama, \& Marpaung, 2017) dan (Yusbardini \& Rashid, 2019) bahwa profitabilitas berpengaruh positif. Bertolakbelakang dengan penelitian (Rani, 2017) menunjukkan bahwa profitabilitas tidak berpengaruh terhadap financial distress. 


\section{Pengaruh Likuiditas terhadap Financial Distress}

Likuiditas digunakan untuk mengukur kemampuan perusahaan dalam melunasi kewajiban jangka pendeknya. Perusahaan yang mampu meningkatkan nilai likuiditasnya, maka perusahaan tersebut akan semakin liquid dan sehat dalam arti perusahaan akan semakin menjauhi potensi financial distress. Namun apabila perusahaan memiliki likuditas yang rendah maka perusahaan tersebut dikwatirkan tidak dapat membayar hutang jangka pendeknya, karena hal tersebut dapat mengindikasikan bahwa perusahaan tidak dalam kondisi liquid karena aset lancar perusahaan tidak dapat menutupi hutang lancarnya sehingga dapat memicu terjadinya financial distress. Hasil penelitan ini mendukung penelitian yang dilakukan oleh (Muhtar \& Aswan , 2017), (Zulaecha \& Mulvitasari, 2018) dan (Yusbardini \& Rashid, 2019) yang hasil penelitiannya likuiditas berpengaruh positif terhadap financial distress.

\section{Pengaruh Leverage terhadap Financial Distress}

Hasil penelitian ini menunjukkan bahwa variabel leverage yang diukur menggunakan Debt Equity Ratio (DER) berpengaruh negatif terhadap financial distress, artinya jika nilai Debt Equity Ratio (DER) tinggi maka mengakibatkan angka financial distress(z-score) semakin rendah dan kecil, karena semakin kecil angka variabel financial distress (z-score) maka menandakan sebuah perusahaan tersebut dalam kondisi keuangan yang kurang sehat.

Leverage digunakan untuk mengukur seberapa besar perusahaan dibiayai dengan hutang. Semakin tinggi Debt Equity Ratio (DER) menunjukkan besarnya komposisi kewajiban jangka panjang yang dimiliki perusahaan yang meingkatkan risiko gagal bayar. Apabila perusahaan dapat mengoptimalkan hutangnya dengan baik maka akan semakin jauh dari ancaman kebangkrutan bagi perusahaan tersebut dan dapat melunasi kewajiban jangka panjangnya agar bisa terhindar dari financial distress. Hasil penelitian ini sejalan dengan penelitian (Fahmiwati \& Luhgiatno, 2017), (Zulaecha \& Mulvitasari, 2018) dan (Yusbardini \& Rashid, 2019) yang hasil penelitiannya menunjukkan bahwa leverage berpengaruh negatif terhadap financial distress.

\section{Pengaruh Aktivitas terhadap Financial Distress}

Hasil penelitian ini menunjukkan bahwa variabel aktivitas yang diukur menggunakan Total Aset Turn Over (TATO) tidak berpengaruh terhadap financial distress. Aktivitas yang diukur dengan menggunakan Total Aset Turn Over (TATO) yang tidak berpengaruh artinya apabila perusahaan memiliki penjualan yang sangat lambat dapat mengakibatkan kerugian dalam perusahaan.

Rasio aktivitas yaitu rasio untuk menilai kemampuan perusahaan dalam melaksanakan aktivitasnya sehari-hari atau kemampuan suatu perusahaan dalam penjualan dan pemanfaatan aktiva yang dimiliki. Rasio aktivitas akan lebih baik apabila ada keseimbangan yang layak antara penjualan dan beragar unsur aset, misalnya persediaan dan aset perusahaam dimana jika rasio aktivitas tidak seimbang maka akan mengalami kondisi financial distress. Hasil penelitian ini bertentangan dengan (Fahmiwati \& Luhgiatno, 2017) dan (Shidiq \& Khairunnisa, 2019) yang menyatakan bahwa rasio aktivitas bepengaruh terhadap financial distress.

\section{Pengaruh Sales Growth terhadap Financial Distress}

Hasil penelitian ini menunjukkan bahwa variabel sales growth berpengaruh positif terhadap financial distress artinya jika penjualan perusahaan meningkat maka nilai sales growth bertambah, hal itu akan meningkatkan angka financial distress (z-score) dimana jika 
nilai z-score semakin besar maka perusahaan tersebut dikatakan sehat atau tidak terjadi financial distress. Sales growth digunakan untuk mengukur pertumbuhan penjualan suatu perusahaan. Sales growth mencerminkan kemampuan penjualannya dari waktu ke waktu. Semakin tinggi tingkat sales growth maka perusahaan berhasil menjalankan strateginya dalam hal pemasaran dan penjualan produk. Hal ini berarti semakin besar pula laba yang diperoleh perusahaan tersebut. Jika laba yang diperoleh oleh perusahaan itu meningkat, maka perusahaan terhindar dari financial distress. Hasil penelitian ini selaras dengan penelitian (Rahayu \& Sopian, 2017) jika sales growth memiliki pengaruh positif terhadap financial distress. Hal ini dikarenakan sales growth yang tinggi belum tentu memiliki beban yang sedikit, sehingga laba yang dihasilkan hanya sedikit dan kemungkinan akan terjadi financial distress.

\section{PENUTUP}

Penelitian ini diharapkan dapat membantu pihak perusahaan dalam meminimalkan kondisi financial distress dengan memperhatikan rasio keuangannya seperti profitabilitas, likuiditas, leverage, aktivitas, dan sales growth. Dengan memperhatikan aspek-aspek tersebut maka diharapkan perusahaan dapat meningkatkan kinerja keuangannya dalam perusahaan agar terhindar dari financial distress. bagi investor yang ingin menginvestasikan sahamnya diharapkan dengan melihat kondisi keuangan perusahaan terutama dari segi keuntungan perusahaan dan hutang perusahaan.

Perusahaan sektor perdagangan yang terdaftar di BEI hanya 25 perusahaan dan yang memenuhi kriteria sampel hanya 19 perusahaan. Penelitian selanjutnya disarankan untuk menambah periode penelitian sehingga diperoleh jumlah sampel yang lebih besar.

Disarankan peneliti selanjutnya menambahkan variabel independen diluar rasio keuangan, seperti good corporate governance, ukuran perusahaan, dan lain-lain.

\section{DAFTAR PUSTAKA}

Aprilianto, M. B. (2019, Juni 25). brilio.net. Diambil kembali dari www.brilio.net: https://www.brilio.net/ekonomi

Carolina, V., Pratama, D., \& Marpaung, E. I. (2017). Analisis Rasio Keuangan untuk Memprediksi Kondisi Financial Distress (Studi Empirir pada Perusahaan Manufaktur yang terdaftar di Bursa Efek Indonesia Periode 2014-2018). Jurnal Akuntansi Maranatha, Vol 9, No 2 ISSN 2085-8698 e-ISSN 2598-4977.

Fahmi, I. (2017). Analisis Laporan Keuangan. Bandung: Alfabeta.

Fahmiwati, N., \& Luhgiatno. (2017). Analisis Pengaruh Rasio Keuangan Terhadap Financial Distress (Studi Kasus Pada Perusahaan Sektor Perdagangan Eceran di Bursa Efek Indonesia Periode 2012-2015). JAB Vol. 3 No. 01 issn 2502-3497.

Ghozali, I. (2016). Aplikasi Analisis Multivariate IBM SPSS 23 Edisi 8. Semarang: Badan Penerbit Universitas Diponegoro.

Ginanjar, Y. (2018). Financial Distress Pada Perspektif Operating Capacity, Profitabilitas, dan Leverage (Studi Pada Perusahaan Manufaktur Sektor Industri Barang Konsumsi Yang 
Terdaftar di Bursa Efek Indonesia Periode 2013-2015). Jurnal Ilmiah Manajemen\&Akuntansi.

Harahap, S. (2013). Analisis Kritis atas Laporan Keuangan. Jakarta: Rajawali Persada.

Kasmir. (2015). Analisis Laporan Keuangan. Jakarta: PT RajaGrafindo Persada.

laporan-keuangan-dan-tahunan. (t.thn.). Diambil kembali dari indonesia stock exchange: https://www.idx.co.id/perusahaan-tercatat

Muhtar, M., \& Aswan, A. (2017). Pengaruh Kinerja Keuangan Terhadap Terjadinya Kondisi Financial Distress Pada Perusahaan Telekomunikasi di Indonesia. Vol 13 No 3.

Rahayu, W., \& Sopian, D. (2017). Pengaruh Rasio Keuangan dan Ukuran Perusahaan Terhadap Financial Distress (Studi Empiris Pada Perusahaan Food and Beverage di Bursa Efek Indonesia).

Rani, D. (2017). Pengaruh Likuiditas, Leverage, Profitabilitas, Agency Cost, dan Sales Growth Terhadap Kemungkinan Terjadinya Financial Distress (Studi Empiris Perusahaan Manufaktur Yang Terdaftar di Bursa Efek Indonesia Tahun 2012-2015). JOM Fekon Vol.4 No.1.

Saragih, H. P. (2019, Juni 24). cnbcindonesia.com/market. Dipetik Juni 30, 2019, dari https://www.cnbcindonesia.com/market

Shidiq, J., \& Khairunnisa. (2019). Analisis Rasio Likuiditas, Rasio Leverage, Rasio Aktivitas, dan Rasio Pertumbuhan Terhadap Financial Distress Menggunakan Metode ALtman Z-Score Pada Sub Sektor Tekstil dan Garmen di BEI Periode 2013-2017. JIM UPB Vol 7 No. 2 p-ISSN 2337-3350 e-ISSN 2549-9491.

Surdayanti, D., \& Dinar, A. (2019). Analisis Prediksi Kondisi Kesulitan Keuangan Dengan Menggunakan Rasio Likuiditas, Profitabilitas, FInancial Leverage, dan Arus Kas. Jurnal Ilmiah Bisnis dan Ekonomi Bisnis Vol. 13 No. 2 ISSN-p 0126-1258.

Vionita, \& Lusmeida, H. (2019). Analisis Pengaruh Kinerja Keuangan dan Good Corporate Governance Terhadap Financial Distress (Studi Kasus Pada Perusahaan Manufaktur Yang Terdaftar di BEI 2014-2017). SAMBIS ISSN 2685-1474.

Yusbardini, \& Rashid, R. (2019). Prediksi Financial Distress Dengan Pendekatan Altman Pada Perusahaan Manufatur di Indonesia. Jurnal Muara Ilmu Ekonomi dan Bisnis, Vol 3, No 1 ISSN 2579-6224.

Zulaecha, H., \& Mulvitasari, A. (2018). Pengaruh Likuiditas, Leverage, dan Sales Growth Terhadap Financial Distress. Jurnal Manajemen Bisnis, Vol 9 No 1 ISSN 2302-3449 eISSN 2580-9490. 